\title{
Organisational culture of construction companies in Lagos State, Nigeria
}

DOI 10.2478/otmcj-2020-0012

Received October 06, 2018; accepted February 16, 2019

\begin{abstract}
The study investigated the cultural features of construction companies in Lagos state and determined the organisational culture profile of the construction companies in the study area, with a view to providing information that could enhance the organisational performance of Nigeria construction firms. Primary data were sourced through the administration of 196 structured questionnaires to 98 construction companies (i.e., two questionnaires per company) represented by their construction professionals and administrative staff. The information elicited from the returned 140 questionnaires (71\% return rate) included features of organisational culture and dominant characteristic element of organisational culture profile of the construction companies. Data collected for this study were analysed using percentages, factor analysis and mean score (MS). The result showed a dominant organisational cultural feature of strategic direction explaining $17.73 \%$ variance in respondent's perception. However, communication (9.66\%), adaptability (8.43\%) and employee involvement (6.88\%) were also relevant. The organisational culture profile showed a predominant market culture (MC) with focus on production and goal accomplishment (MS = 3.62), a hierarchy culture (HC) of a coordinator, organiser and efficiency expert $(\mathrm{MS}=3.60)$ and an ad hoc culture with strategic emphasis on dynamics and readiness ( $M S=3.56$ ). The family type of culture is undermined within the companies (MS = 3.47). The study concluded that strategic direction being a MC feature corroborates a predominant MC revealed by assessing organisational culture of construction companies in Lagos state, Nigeria.
\end{abstract}

Keywords: organisation, culture, organisational culture, construction companies, Lagos State

\footnotetext{
*Corresponding author: Alao, T.O., Department of Building, Obafemi Awolowo University, Ile-ife, Ibadan, Oyo Nigeria, E-mail: alaoniyi@ yahoo.com

Aina, 0.0., Professor, Obafemi Awolowo University, Ile-ife, Nigeria
}

\section{Introduction}

Organisational culture may be defined as the shared basic assumptions, values and beliefs that characterise a setting and are taught to newcomers as the proper way to think and feel, communicated by the myths and stories; people tell about how the organisation came to be, the way it is, as it solved problems associated with external adaptation and internal integration (Schein 2010; Schneider et al. 2013). The concept of organisational culture was first noted as early as the Hawthorne studies at the Western Electric Company, which described work group culture (Mayo 1933; Roethlisberger and Dickson 1939). It was not until the early 1980s that the concept came into limelight, credited largely to the economic conditions of the 1970s when international competition heightened and more foreign companies were operating factories in the United States. Specifically, the success of the Japanese in many industries sparked curiosity about whether their differing corporate values, attitudes and behaviours were responsible for their often superior performance. Pettigrew (1979) introduced the anthropologist concepts such as "symbolism", "myths" and "rituals" that could be used in organisational analysis.

Developing organisational culture has several important purposes and benefits. First, it conveys a sense of identity for organisation members. Second, it facilitates the generation of commitment (Peters and Waterman 1982). Third, culture serves as a sense-making device that can guide behaviour (Siehl and Martin 1988 in Cheung et al. 2010). Brown (1995) identified a large number of functions that can be attributed to organisational culture and these include the following: conflict resolution, coordination and control, motivation and competitive advantage (Brown 1995; Maleka et al. 2015). Organisational culture types influence tacit knowledge sharing behaviour positively or negatively depending on the culture type (Suppiah and Sandhu 2012) and enhance the success of major initiatives such as mergers, reorganisations, attitude change programmes and Total Quality Management (TQM) (Bath Consultancy Group, Culture 
Analysis 2006). Organisational culture also determines the level of maturity of the business of the organisation (Abiola-Falemu 2008) and can be used to promote the achievement of job satisfaction and employee commitment (Abiola-Falemu 2013).

There is a need not to neglect organisational culture in decision making. Scandals, puzzles and perceived hypocrisy are common in organisations that fail to consider organisational culture (Madu 2008; Nelson and Weaver 2014; Gutner and Thompson 2010). Hence, if the Nigerian construction industry pays attention to organisational culture, it can improve these disadvantages and thus contribute to its efficiency. Organisational culture has evolved standard procedures (tendering procedures, contract) defined by characteristic traits and features to help ensure that the performance specified is secured (Fellows and Liu 2006). Common features include collaboration and cooperation, supportiveness, team approach, reward and incentive orientation, competitiveness, commitment and involvement, adaptability and confidence in leadership, among others. If the industry integrates organisational culture into its practices, it can improve its performance.

\subsection{Statement of the problem}

Organisational culture compares the prevailing culture with the ideal to evolve a better organisational performance. In the past few years, it has gained attention as one of the central elements that contribute to organisational success and performance (Choi et al. 2010). Its unique nature in terms of cultural type and strength allows an organisation to change the emphasis on certain values and shift to the values peculiar to the cultural type with highest strength (Choi et al. 2010) although project participants measuring organisational culture have different criteria, because their cultural fundamentals comprise differing beliefs and values (Abu-Jarad et al. 2010). Cameron and Quinn (1999) suggested that measures used for strengths of cultures are significantly questionable.

Organisational performance of construction companies is significantly below expectations due to poor forecasts, poor realisation of project objectives or both (Fellows and Liu 2006). Aniekwu and Igboanugo (2012) reported that it is apparent that the Nigeria construction industry has failed to maintain parity with other sectors such as the retail, automotive, electronics and aerospace industries despite obvious short-term successes (using indices of productivity) and the divergence is increasing yearly (Bew and Richards 2008). Thus, there is a need for the industry to improve and keep improving its efficiency. However, the obstacles and uncertainties facing the industry due to changing environment can only be addressed when there is a means for assessing construction organisations (Maloney and Federle 1993). Hence, organisational culture is one of such means for assessing construction organisations. Magee (2002) contended that without considering the impact of organisational culture, organisational practices such as performance management could be counterproductive because the two are interdependent and change in one will impact the other.

Research on organisational culture especially in the construction industry is limited (Ankrah 2007). A lot of research studies in organisational theory have focused on developed countries (95\%), whereas only $5 \%$ of the studies are found to be carried out in developing countries (Farashahi et al. 2005: Ahmad 2012). Novana and Ogunlana (2006) assessed the organisational culture profile of construction companies in Thailand and reported that the hierarchy culture (HC) is predominant, followed by market, clan and adhocracy. Thai contracting companies do not focus on innovation, growth and response acquisition. Oney-Yazic et al. (2007) investigated the cultural features and profile of US construction companies and reported that the organisations are dominated by a strong clan culture (CC), which is relevant to internally focused organisations. In Nigeria, there is a dearth of studies on organisational culture of construction companies. Although Olanipekun et al. (2013) studied the effects of organisational culture on the performance of quantity surveying firms in Nigeria using an assessment approach comprising dimensions suited to service organisations like quantity surveying firms rather than construction companies that produce buildings. Abiola-Falemu (2013) studied the relationship between organisational culture, job satisfaction and employee commitment, which impact on and could be an antithesis to poor performance problem of the construction industry; however, the absence of a two-way approach to measuring and confirming organisational culture of construction companies in Lagos State, Nigeria, leaves a lot of questions that could unravel the fundamental organisational culture issues in the Nigeria construction industry unanswered. Such issues include identification of the prevailing organisational culture in the industry and its features and profile. These are the stimuli for this study and they raise the following research questions.

1. What are the features of organisational culture exhibited by construction companies in Lagos State, Nigeria?

2. What is the organisational culture profile of the construction companies in the study area? 


\section{Literature review}

\subsection{Definition of organisational culture}

On the definition of organisational culture, most authors agreed that organisational or corporate culture referred to something that is holistic, historically determined (by founders or leaders), related to things anthropologists study (such as rituals and symbols), socially constructed (created and preserved by the group of people who together form the organisation), soft and difficult to change (Abu-Jarad et al. 2010). Organisational culture can be observed at three levels of the organisation as follows: artefacts, espoused values and basic assumptions, and these levels can be analysed by the degree of visibility to observers (Schein 2004). According to Maleka et al. (2015), Schein's (1992) model distinguishes the following three levels of culture: artefacts (visible, tangible, audible results of activity grounded in values and assumptions), values (social principles, philosophies, goals and standards considered to have intrinsic worth) and basic assumptions (taken-for-granted beliefs concerning reality and human nature). This coheres with Hofstede's (1999) ideas about underlying worldviews that are manifested in a "collective programming of the mind". However, Lunenburg (2011) viewed organisation's culture as consisting of outcomes that the organisation seeks to achieve and the behavioural procedures or procedural behaviours the organisation encourages for doing things. They become personalities on their own just like people with the face of the leader and can be flexible or rigid, supportive or unfriendly and innovative or conservative (Lunenburg 2011). People exchange values with the person of the organisation in a transaction like camaraderie among themselves (Kotler 1972). The experience is business.

These definitions of organisational culture, its component levels and examples are summed up in Figure 1.

\subsection{Organisation culture features}

Organisational culture can be described by its aspect, features, dimensions, traits and elements. Scientists use different concepts that have the same meaning (Ginevičius and Vaitkūnaitè 2006). Features of organisational culture are used to assess organisational culture and to evaluate its relationship with organisational performance. Jung et al. (2009) identified prominent dimensional features by surveying a host of renown instrument. These include the following: achievement or accomplishment, attitudes to change or creating change, employee development capability, employee commitment or participation, valuing of ethics, long-term customer focus, goal clarity or orientation, innovativeness or risk taking, job satisfaction or job
Levels of Culture

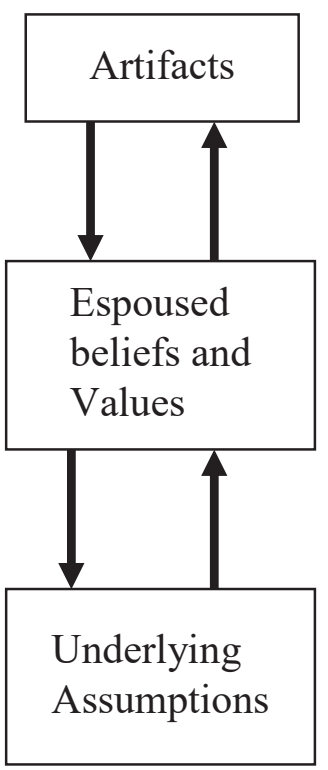

Examples

Visible organizational

structures and processes

Strategies, goals, philosophies

\section{Unconscious}

been taken-for- granted beliefs, of perceptions, thoughts and feelings
Characteristics

Surface but hard to decipher

\section{Sharing with espoused justification}


security, confidence in leadership, individual learning and organisational learning, organisational identity and attributes, performance facilitation measures, power, relationships (collegial or interdisciplinary relations), results, rewards, supportiveness, task structure, team approach and trust. Ginevičius and Vaitkūnaitè (2006) analysed 53 works in selecting organisational culture features and came out with a final list of 12 features which includes the following: involvement, cooperation (collaboration), transmission of information, learning, care about clients, adaptability, strategic direction, reward and incentive system, system of control, communication, agreement, coordination and integration. These features are broken down into hierarchical structure and corrected as presented in Figure 2.

\subsection{Types of organisational culture}

The organisational culture assessment tool assesses four culture types based on six different dimensions as follows: (i) dominant characteristics (culture type), (ii) organisational leadership, (iii) management of employees, (iv) organisational glue, (v) strategic emphases and (vi) criteria for success. It was originally developed to understand organisational effectiveness (Cameron and Quinn 1999) and was later applied to explore different issues relative to organisations such as TQM (Al-Khalifa and Aspinwall 2001), leadership development and managerial styles (Martin and Simons 2000) and finally organisational culture (Cameron and Quinn 1999). It encompasses four quadrants, each representing a different set of organisational culture indicators. Each quadrant is given a distinguishing label that denotes its most notable cultural characteristics, namely, (1) clan or family, (2) adhocracy or ad hoc, (3) market and (4) HCs. This is presented in Figure 3.

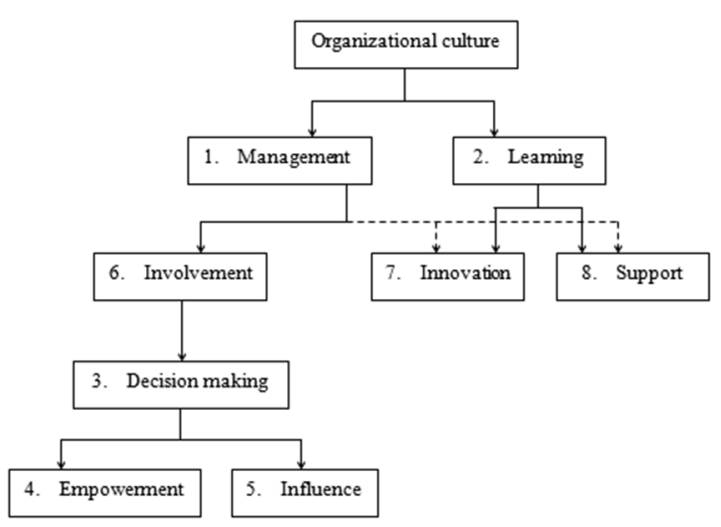

Fig. 2: Corrected relationships between dimensions. Source: Ginevičius and Vaitkūnaitė (2006).

\section{Research methodology}

Primary data were sourced through the administration of 196 structured questionnaires to 98 construction companies (i.e., two questionnaires per company) represented by their construction professionals and administrative staff. The information elicited from the returned 140 questionnaires ( $71 \%$ return rate) included features of organisational culture and dominant characteristic element of organisational culture profile of the construction companies. Data collected for this study were analysed using percentages, factor analysis and mean score (MS). The questionnaire was divided into three sections as follows: general information, organisational culture features and organisational culture profile. Item statements from Ginevičius and Vaitkūnaitē's modified instrument of organisational culture assessment and others were used for analysing the organisational culture features because the existing culture measurement instruments were put into consideration in the instrument. The organisational culture assessment instrument was used for determining the cultural profile. It assesses six key elements of organisational culture, each element having four statements representing each culture type. The questionnaire was presented with a series of statements characterising dimensions (or features) using a five-point Likert scale. Respondents were asked to give labels ranging from "never true" or "completely true" to each statement and each given a numerical score to reflect the degree of attitudinal favourableness. The use of an assessment instrument is still considered to be an appropriate practice in the study of organisations since it encompasses numerous relevant features (Ankrah and Langford 2005). To construct an organisational culture profile, the average MS of each culture was plotted on a diagonal line and the organisational culture profile interpreted based

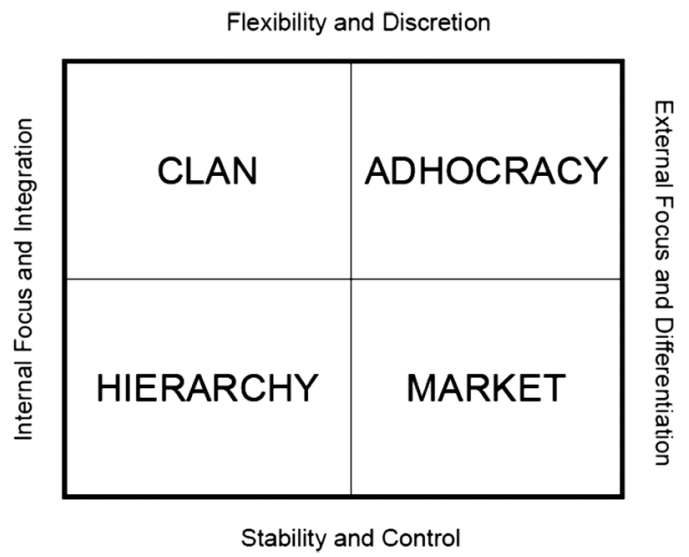

Fig. 3: The Competing Values Framework. Source: Cameron and Quinn (2006). 
on the picture. The culture with the highest average score was considered to be the strongest and dominant culture.

\section{Data analysis and discussion of results}

\subsection{General information of respondents}

The general information of respondents is presented in Table 1, whereas Table 2 shows the types of construction contracts undertaken by the companies. Result revealed that a majority of respondent professionals had Bachelor of Science (BSc) $(f=62,44.3 \%)$. This is followed by Masters (MBA/March/MSc) $(f=39,27.9 \%)$, Higher National Diploma (HND) $(f=31,22.1 \%)$, Ordinary National Diploma (OND) $(f=6,4.3 \%)$ and NCE $(f=2,1.4 \%)$. Most of the companies had been operating for 6-10 years $(f=38,27.1 \%)$, followed by $11-15$ years $(f=35,25.0 \%), 16-20$ years $(f=24,17.1 \%)$, above $20(f=24,17.1 \%)$ and $0-5$ years $(f=19,13.6 \%)$. Builders responded most to the research $(f=55,39.3 \%)$, then, Architects $(f=30,21.4 \%)$, Engineers $(f=26,18.6 \%)$, Public administration staff $(f=12,8.6 \%)$, Office managers $(f=9$, 6.4\%), Facility managers $(f=4,2.9 \%)$ and Accountants and Quantity surveyors $(f=2,1.4 \%)$. Sixty five (46.4\%) of the respondents have $0-5$ years professional experience, 56 respondents (40.0\%) have 6-10 years, eleven respondents (7.9\%) have 11-15 years, whereas four respondents (2.9\%) have 16-20 and above 20 years each. Respondents' professional qualification showed predominant absence of membership ( $f=54, f=38.6 \%$ ). This is followed by membership of the Nigerian Institute of Building (MNIOB) $(f=28,20.0 \%)$, National Society of Engineers (NSE) $(f=20,14.3 \%)$, Nigerian Institute of Architecture (NIA) $(f=20,14.3 \%)$, National Institute of Management (NIM) $(f=8,5.7 \%)$, ICAN $(f=4,2.9 \%)$, Chartered Institute of Personnel Management in Nigeria (CIPM) $(f=2,1.4 \%)$, NIQS $(f=2,1.4 \%)$ and Occupational Safety and Health (OSH) $(f=2,1.4 \%)$. Most of the construction companies surveyed within the study location worked more on private projects $(f=89,63.6 \%)$, then, both public and private projects $(f=$ $31,22.1 \%)$ and public projects $(f=20,14.3 \%)$.

\subsection{Factor analysis of organisational culture features}

The study adopted factor analysis to reduce the item statements and consequent features to principal components. The value of Kaiser-Meyer-Olkin (RMD, 0.575) measure of
Tab. 1: General information of respondents

\begin{tabular}{|c|c|c|}
\hline & Frequency $(f)$ & Percentage \\
\hline \multicolumn{3}{|l|}{ Educational qualification } \\
\hline OND & 6 & 4.3 \\
\hline HND & 31 & 22.1 \\
\hline BSc & 62 & 44.3 \\
\hline MBA/MArch/MSc & 39 & 27.9 \\
\hline NCE & 2 & 1.4 \\
\hline \multicolumn{3}{|l|}{ Respondent's profession } \\
\hline Architect & 30 & 21.4 \\
\hline Builder & 55 & 39.3 \\
\hline Engineer & 26 & 18.6 \\
\hline Quantity surveyor & 2 & 1.4 \\
\hline Accountant & 2 & 1.4 \\
\hline Facility manager & 4 & 2.9 \\
\hline Office manager & 9 & 6.4 \\
\hline Public admin/secretary & 12 & 8.6 \\
\hline Total & 140 & 100 \\
\hline \multicolumn{3}{|c|}{ Year of company's operation } \\
\hline $0-5$ & 19 & 13.6 \\
\hline 10-Jun & 38 & 27.1 \\
\hline 15-Nov & 35 & 25 \\
\hline $16-20$ & 24 & 17.1 \\
\hline Above 20 & 24 & 17.1 \\
\hline Total & 140 & 100 \\
\hline \multicolumn{3}{|c|}{ Number of years of professional experience } \\
\hline $0-5$ & 65 & 46.4 \\
\hline 10-Jun & 56 & 40 \\
\hline 15-Nov & 11 & 7.9 \\
\hline $16-20$ & 4 & 2.9 \\
\hline Above 20 & 4 & 2.9 \\
\hline Total & 140 & 100 \\
\hline \multicolumn{3}{|c|}{ Respondents' professional qualification } \\
\hline NSE & 20 & 14.3 \\
\hline NIA & 20 & 14.3 \\
\hline NIOB & 28 & 20 \\
\hline NIQS & 2 & 1.4 \\
\hline NIM & 8 & 5.7 \\
\hline CIPM & 2 & 1.4 \\
\hline ICAN & 4 & 2.9 \\
\hline $\mathrm{OSH}$ & 2 & 3.6 \\
\hline No qualification & 54 & 38.6 \\
\hline Total & 140 & 100 \\
\hline \multicolumn{3}{|l|}{ Types of project } \\
\hline Public & 20 & 14.3 \\
\hline Private & 89 & 63.6 \\
\hline Both & 31 & 22.1 \\
\hline Total & 140 & 100 \\
\hline
\end{tabular}

sampling adequacy test carried out (Table 2) showed that the data collected were adequate for the analysis, and the Barlett's test of sphericity (0.000) was highly significant. Thus, the data upon which the analysis was carried out 
Tab. 2: Factor analysis, Kaiser-Meyer-Olkin (KMO) index and Bartlett's test

\begin{tabular}{lll}
\hline KMO and Bartlett's test & \\
\hline KMO measure of sampling adequacy & 0.575 \\
Bartlett's test of sphericity & Approx. Chi-Square & $1,515.086$ \\
& Df & 435 \\
& Sig. & 0.000 \\
\hline
\end{tabular}

Tab. 3: Total variance explained

\begin{tabular}{lccc}
\hline Factors & $\begin{array}{c}\text { Total Eigen } \\
\text { value }\end{array}$ & $\begin{array}{c}\text { Percentage } \\
\text { of variance }\end{array}$ & $\begin{array}{c}\text { Cumulative } \\
\text { percentage }\end{array}$ \\
\hline Strategic direction & 5.318 & 17.726 & 17.726 \\
Communication & 2.899 & 9.662 & 27.388 \\
Adaptability & 2.530 & 8.433 & 35.820 \\
Involvement & 2.063 & 6.875 & 42.695 \\
Reward orientation & 1.660 & 5.534 & 48.229 \\
Agreement & 1.494 & 4.981 & 53.210 \\
Coordination and integration & 1.428 & 4.760 & 57.970 \\
Organisational learning & 1.309 & 4.362 & 62.332 \\
Confidence in leadership & 1.193 & 3.978 & 66.310 \\
\hline
\end{tabular}

were reliable. The total variance explained by the factors (30 factors) is shown in Table 3. By considering a cut-off point for the score loading with absolute value greater than 0.500 , the components and the corresponding critical factors loading are presented in Tables 4 and 5.

All (nine) components were extracted via principal component analysis with Eigen values greater than 1.000 (Figure 4). The extracted nine components explain approximately $66.3 \%$ variability in the original 30 variables. The rotation sums of squared loadings revealed percentage of variables accounted for by extracted components as listed in a uniformly distributed manner of $17.73 \%, 9.66 \%, 8.43 \%, 6.88 \%, 5.53 \%, 4.98 \%, 4.76 \%, 4.36 \%$ and $3.98 \%$, respectively.

\subsection{Summary of factors and corresponding MS}

Table 5 shows the summary of factors as given by factor analysis and also their corresponding MS to buttress factor scores for the purpose of ranking. The first component in the analysis is mostly correlated with strategic direction. This factor has an Eigen value of 5.32 and a percentage variance of $17.73 \%$ with statements including 'the company works with specific strategies, plans and a long term goal' (0.780), 'the company reflects a leader showing direction and employees follow it' (0.772), 'if a client is dissatisfied, it is duly noted and removed' (0.594) and 'there is continuous improvement of service quality' (0.547). Hellriegel et al. (2004) opined that the achievement of measurable and demanding goals, especially those that are finance-based and market-based are characteristics of a market culture (MC). Employees focus personal energy in the pursuit of common goals to realise the organisation's common vision or purpose (Harrison and Stokes 1992). This intone a mission culture orientation as it reflects that the organisation's strategic direction, goals and vision are clearly defined and are comprehended by employees (Maleka et al. 2015). This mission culture orientation is viewed by Baker (2002) to be in congruence with Cameron and Quinn's MC. Customer satisfaction and service quality are regarded as measures of competitiveness and performance, which is core to a market-oriented culture.

The second component is highly correlated with communication issues. This component has an Eigen value of 2.90 and a percentage variance of $9.66 \%$ with 'managers advices and attitudes are always at variance' (0.799), 'managers are authoritative' $(0.726)$, 'the person who is the leader of a work group is often recognised as being more important than the company' (0.537) and 'employees and/ or managers often misunderstand each other' (0.501). This is supportive of an $\mathrm{HC}$ where communication, routinisation and formalisation are core values and people behave appropriately when procedures are formally defined by rules and regulations (Hartnell et al. 2011). Managers within a bureaucratic or hierarchical culture setting are good coordinators and enforcers of rules and procedures that are clearly defined. Tasks, responsibilities and authority for employees are also clearly stated (Hellriegel et al. 2004). As also reported by Alkhamali (2014), this kind of culture features control and formality, and leaders use their power and authority to influence organisations' members. Also, the possibility of conflicts and disputes is associated with hierarchical culture due to the weakness of people and internal focus.

The third component is most highly correlated with adaptability concerns. The component has an Eigen value of 2.53 and a percentage variance of $8.43 \%$. It comprises 'employees most often agree when solving problems or conflicts' (0.842), 'existing rules and norms show more of direction than restrictions' (0.530) and 'sometimes there are situations when norms are only partially followed' (0.527). This implies that employees react to change, as well as creating change due to the fact that individual initiative, flexibility and freedom promoting growth are encouraged and rewarded (Hellriegel et al. 2004). This is corroborated by the low rank of item statements 22 
Tab. 4: Factor analysis: rotated component matrix

Factors

Components

Factor 1 Factor 2 Factor 3 Factor 4 Factor 5 Factor 6 Factor 7 Factor 8 Factor 9

The company works with specific strategies, plans and a long-term goal

The company reflects a leader showing direction and employees "follow it"

If a client is dissatisfied, it is duly noted and removed

There is continuous improvement of service quality

Managers' advices and attitudes are always at variance

Managers are authoritative

The person who is the leader of a work group is often recognised as being more important than the company

Employees and/or managers often misunderstand each other

Employees most often agree when solving problems or conflicts

Existing rules and norms show more of direction than restrictions

Sometimes there are situations when norms are only partially followed

There is investigation of product characteristics and personnel needs

Employees have favourable conditions for decision making and for giving ideas, suggestions and so on Factor Analysis. Rotated Component Matrix

Training programmes are encouraged to enhance skill of employees

Feedback, new or other important information reaches employee in due time

There are fringe benefits and managers prioritise the welfare of employees

Employees agree about most rules, norms and values Employees have too much freedom and autonomy

Different departments (groups) have many common things (goals, tasks etc.)

There are created good conditions for the interesting work, therefore employees get used to their work willingly

Reward system is correct (employees get paid according to results and efforts)

Managers are eager to advise employees and motivate with charisma

Team approach is used more than individual work especially when solving important questions on a project

Sanctions and punishment are sometimes overlooked, i.e., managers get away from regulations and try another solution

There is great dependence on the leaders of the company
0.780

0.772

0.594

0.547

0.799

0.726

0.537

0.501 
Tab. 5: Summary of factors and corresponding mean score

\section{Factors}

Strategic direction

- The company works with specific strategies, plans and a long-term goal

- The company reflects a leader showing direction and employees "follow" it

- If a client is dissatisfied, it is duly noted and removed

- There is continuous improvement of service quality

Communication

- Managers advices and attitudes are always at variance

- Managers are authoritative

- The person who is the leader of a work group is often recognised as being more important than the company

- Employees and/or managers often misunderstand each other

Adaptability

- Employees most often agree when solving problems or conflicts

- Existing rules and norms show more of direction than restrictions

- Sometimes there are situations when norms are only partially followed

- It is difficult for employees to adapt to changes in culture and they sometimes resist it

Involvement

- There is investigation of product characteristics and personnel needs

- Employees have favourable conditions for decision making and for giving various ideas, suggestions, notes and so on

Reward orientation

- Training programmes are encouraged to enhance skills of employees

- New or other important information reaches employees in due time

- There are fringe benefits and managers prioritise the welfare of employees

Agreement

- Employees agree about most rules, norms and values

- Employees have too much freedom and autonomy

Coordination and integration

- Different departments (groups) have many common things (goals, tasks etc.)

- Reward system is correct (employees get paid according to the results and efforts)

Organisational learning

- Managers are eager to advise employees and motivate with charisma

- Team approach is used more often than individual work especially when solving important questions on a project

Confidence in leadership

- Sanctions and punishment are sometimes overlooked, i.e., managers get away from regulations and try another solution

- There is great dependence on the leaders of the company
3.5580

3.5580

3.4779

2.4203

3.5294

3.6397

3.2391

Rank

4




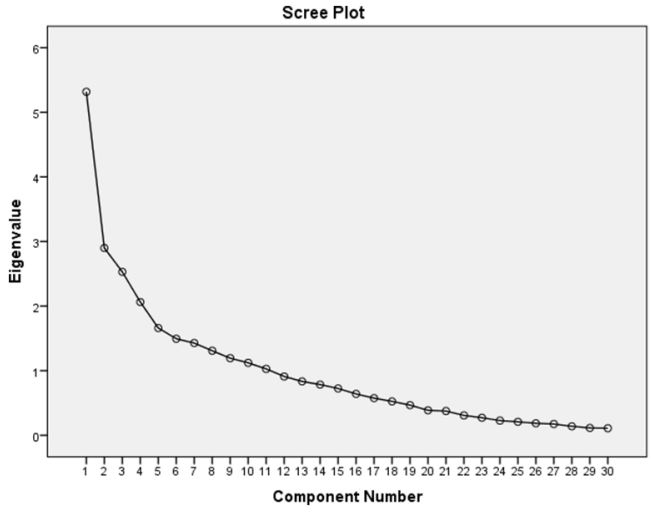

Fig. 4: Scree plot

(mean $=2.6194)$ : 'It is difficult for employees to adapt to changes in culture and they sometimes resist it.' These attributes typify a dynamic or adhocracy culture.

The fourth component is highly correlated with employees' involvement. This component has an Eigen value of 2.06 , a percentage variance of $6.88 \%$ and had factor loading of 'there is investigation of product characteristics and personnel needs' (0.820) and 'employees have favourable conditions for decision making and for giving various ideas, suggestions, notes and so on' (0.510). Employees strive to meet up with standard requirements and keep improving (mean $=4.1159$, rank 1 ). There is focus on the growth of the organisation's employees through problem solving and effective planning. These attributes typify a quality culture, and it is more flexible in its approaches and therefore more accepting when change occurs. It also has a strong technical orientation within an organisation (Maleka et al. 2015).

The fifth component is most highly correlated with reward orientation with an Eigen value of 1.66 and a percentage variance of $5.53 \%$. This component has 'training programs are encouraged to enhance skills of employees' (0.743), 'new or other important information reaches employees in due time' (0.709) and 'there are fringe benefits and managers prioritize the welfare of employees' (0.511). This is to enrich the job design of the construction companies in focus and to lubricate the work environment.

The sixth component 'Agreement' has an Eigen value of 1.49 and accounted for $4.98 \%$ of the total variance. This component has the factor loadings of 'employees agree about most rules, norms and values' (0.786) and 'employees have too much freedom and autonomy' (0.642).

The seventh component in the analysis is most highly correlated with coordination and integration. This component has an Eigen value of 1.43 and a percentage variance
Tab. 6: Organisational culture profile

\begin{tabular}{|c|c|c|}
\hline Dominant characteristics & Mean & $\begin{array}{l}\text { Overall } \\
\text { rank }\end{array}$ \\
\hline Clan culture (CC) & 3.4681 & 4 \\
\hline Adhocracy culture (AC) & 3.5622 & 3 \\
\hline Market culture (MC) & 3.6188 & 1 \\
\hline Hierarchy culture (HC) & 3.6036 & 2 \\
\hline Organisational leadership & & Rank \\
\hline There is mentoring $(\mathrm{CC})$ & 3.3261 & 4 \\
\hline Entrepreneur, innovator or a risk-taker (AC) & 3.4779 & 2 \\
\hline Hard-driver, producer or competitor (MC) & 3.3456 & 3 \\
\hline $\begin{array}{l}\text { Coordinator, organiser or an efficiency } \\
\text { expert (HC) }\end{array}$ & 3.7029 & 1 \\
\hline \multicolumn{3}{|l|}{ Management of employees } \\
\hline $\begin{array}{l}\text { Presence of teamwork, consensus, and } \\
\text { participation (CC) }\end{array}$ & 3.5217 & 3 \\
\hline $\begin{array}{l}\text { Innovation, freedom and uniqueness is } \\
\text { encouraged (AC) }\end{array}$ & 3.6812 & 2 \\
\hline Production and achievement orientation (MC) & 4.0072 & 1 \\
\hline $\begin{array}{l}\text { Security of employment (job stability) and } \\
\text { predictability }(\mathrm{HC})\end{array}$ & 3.4412 & 4 \\
\hline \multicolumn{3}{|l|}{ Organisational glue } \\
\hline Existence of loyalty and tradition (CC) & 3.2464 & 4 \\
\hline Innovation and development (AC) & 3.5362 & 3 \\
\hline $\begin{array}{l}\text { Focus on production and goal accomplishment } \\
\text { (MC) }\end{array}$ & 4.0870 & 1 \\
\hline Rules and Policies (HC) & 3.6565 & 2 \\
\hline \multicolumn{3}{|l|}{ Strategic emphases } \\
\hline Participative and comfortable atmosphere (CC) & 3.3551 & 3 \\
\hline Dynamics and readiness (AC) & 3.5217 & 1 \\
\hline $\begin{array}{l}\text { Atmosphere is competitive and confrontational } \\
\text { (MC) }\end{array}$ & 3.2426 & 4 \\
\hline There is permanence and stability (HC) & 3.4058 & 2 \\
\hline \multicolumn{3}{|l|}{ Criteria of success } \\
\hline $\begin{array}{l}\text { There is sensitivity to customers, concern } \\
\text { for people (CC) }\end{array}$ & 3.8913 & 1 \\
\hline Product leader and innovator (AC) & 3.5942 & 3 \\
\hline Market penetration and market share (MC) & 3.4118 & 4 \\
\hline $\begin{array}{l}\text { Dependable delivery, smooth scheduling } \\
\text { of task }(\mathrm{HC})\end{array}$ & 3.8116 & 2 \\
\hline
\end{tabular}

of 4.76\%. It comprises 'different departments (groups) have many common things (goals, tasks etc.) (0.816), there are created good conditions for the interesting work, therefore employees get used to their work willingly (0.661), reward system is correct (employees get paid according to the results and efforts' (0.584).

The eighth component in the analysis is most highly correlated with organisational learning. This component has an Eigen value of 1.31 and a percentage variance of 
$4.36 \%$ with 'managers are eager to advise employees and motivate with charisma' (0.759), 'team approach is used more often than individual work especially when solving important questions on a project' $(0.647)$.

The ninth component shows confidence in leadership with an Eigen value of 1.19 and a percentage variance of $3.98 \%$. It has 'sanctions and punishment are sometimes overlooked. i.e. managers get away from regulations and try another solution' (0.857) and 'there is great dependence on the leaders of the company' (0.703) $($ mean $=3.7971$, rank 9).

\subsection{Organisational culture profile from assessment instrument}

Table 6 shows the Organisational Culture Profile of the construction companies sampled. Mean response analysis was used to rate the elements under the five dimensions (i.e. organisational leadership, management of employee, organisational glue, strategic emphases and criteria of success) presented in the assessment instrument and the aggregate score of the four culture types (CC, adhocracy culture $[\mathrm{AC}], \mathrm{MC}$ and $\mathrm{HC}$ ) calculated by average. Findings reveal a predominant MC with the highest score (3.6188). This is followed by HC (3.6036), AC (3.5622) and CC (3.4681). This is represented in Figure 5, and it agrees with the study by Abiola-Falemu (2013) who discovered that a people or CC appears to be subjugated within the industry. This is probably because of the nomadic nature of the industry and that most of the construction companies are not disposed to having an organisational setting where their employees would work as a family. Also, the number of respondent decreases across increasing number of years of professional experience, meanwhile, a reasonably stable membership is assumed to be necessary to produce social understandings by Schein (1981), in other words to develop clan characteristics. The development of a MC is expected above other forms in Lagos, a place often adjudged the business capital of Nigeria.

\section{Conclusion and recommendations}

The study concluded that a dominant organisational cultural feature of strategic direction is prevalent in construction companies in the study area. However,

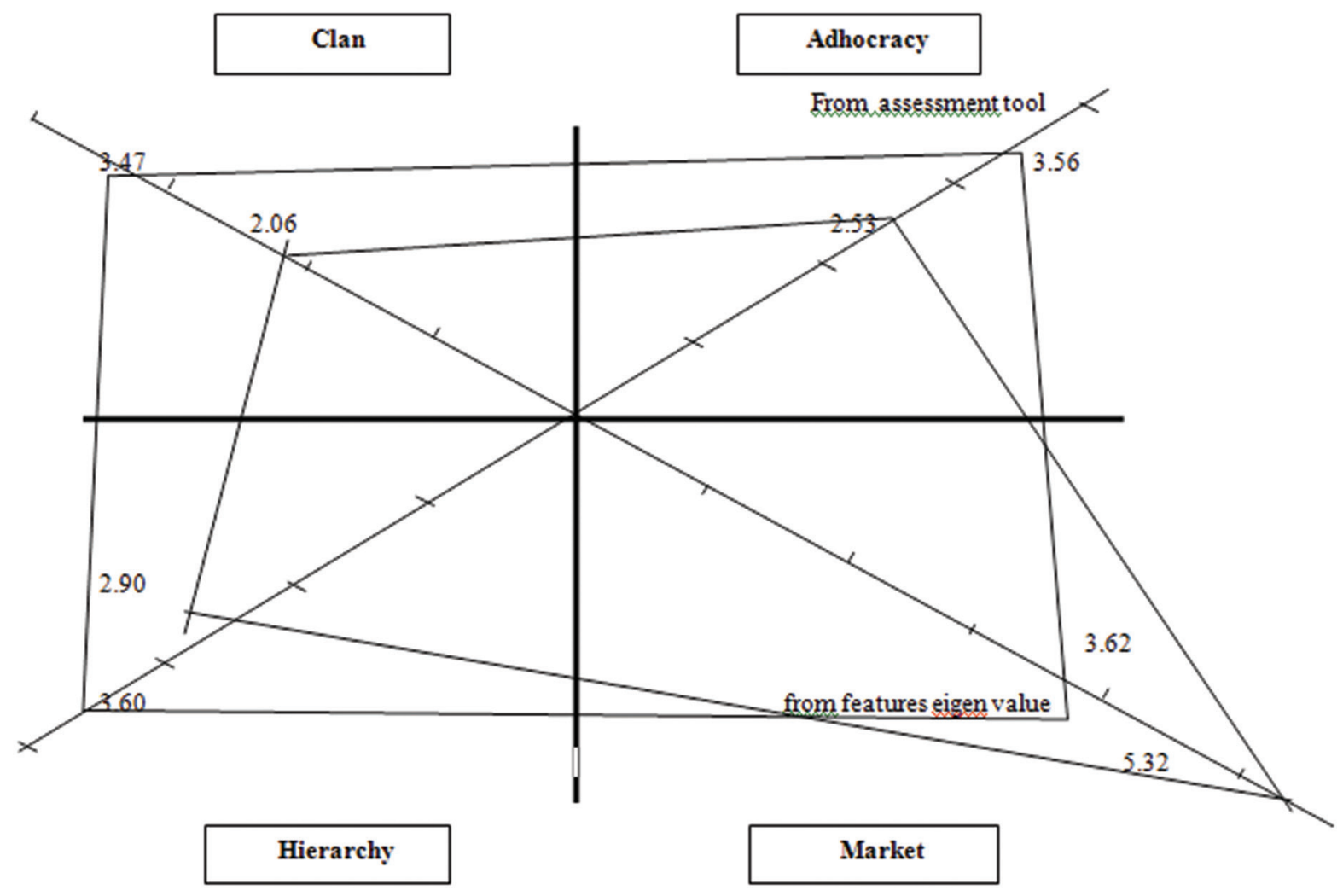

Fig. 5: Organisational culture profile 
communication, adaptability and employee involvement are also relevant. These features pointed to a MC, HC, AC and family or CC in that order. This was verified by the organisational culture profile drawn from an aggregated score using an assessment instrument that also showed a predominant MC with focus on production and goal accomplishment. The family type of culture is undermined within the companies. Based on the findings of the study and conclusion drawn, the author recommends that leaders of construction companies in Lagos State create an atmosphere of reward to encourage a family existence, i.e. CC and consequent cooperation among professionals.

\section{References}

Abiola-Falemu, J. O. (2013). Organizational culture, job satisfaction and commitment of lagos-based construction workers. IOSR Journal of Business and Management (IOSR-JBM), 13(6), pp. 108-120.

Abiola-Falemu, J. O., Ogunsemi, D. R., \& Oyediran, O. S. (2010). Assessment of organizational culture and innovation practices of construction companies in Southwest Nigeria. In: Conference of Chartered Institute of Bankers (CIB18940), pp. 218-233.

Abu-Jarad, I. Y., Yusof, N., \& Nikbin, D. (2010). A review paper on organizational culture and organizational performance. International Journal of Business and Social Science, 1(3).

Ahmad, M. S. (2012). Impact of organizational culture on performance management practices in Pakistan. Business Intelligence Journal, 5(1), pp. 50-55.

Al-Khalifa, K., \& Aspinwall, E. M., (2001). Using the competing values frameworks to investigate the culture of Qatar industries. Total Quality Management, 12(4), pp. 417-428.

Alkhamali, K. S. H. (2014). Leadership style, organizational culture and disputes in public construction. A PhD thesis, Heriot-Watt University School of the Built Environment.

Ankrah, A. N. (2007). An investigation into the impact of culture on construction project performance. An Unpublished PhD thesis, University of Wolverhampton, UK, 2007.

Ankrah, N. A., \& Langford, D. A. (2005). Architects and contractors: A comparative study of organizational cultures. Construction Management and Economics, 23(5), pp. 595-607.

Baker, K. A. (2002). Organizational Culture, Chapter 11.06.08.02. doc. Available at http://www.au.af.mil/au/awc/awcgate/doe/ benchmark/ch11.

Bath Consultancy Group, Culture Analysis. (2006). Available at http://www.bathconsultancygroup.com/.Author on 27 September, 2006.

Cameron, K. S., \& Quinn, R. E. (1999). Diagnosing and Changing Organizational Culture. Addison-Wesley Publishing, Reading, MA.

Cheung, S. O., Wong, P. S. P., \& Wu, A. W. Y. (2010). Towards an organizational culture framework in construction. International Journal of Project Management, 29, pp. 33-44.

Choi, Y., Seo, M., Scott, D., \& Martin, J. J. (2010). Validation of the organizational culture assessment instrument: An application of the Korean version. Journal of Sport Management, 24(2), pp. 169-189. Available at: http://digitalcommons.wayne.edu/ coe_khs/30.

Fellows, R., \& Liu, A. (2006). Culture as a Category of Risk in Construction. Conference of Chartered Institute of Bankers Conference (CIB), pp. 138-147.

Ginevičius, R., \& Vaitkūnaitè, V (2006). Analysis of organizational culture dimensions impacting performance. Journal of Business Economics and Management, 7(4), pp. 201-211.

Gutner, T., \& Thompson, A. (2010). The politics of IO performance: A framework. Review of International Organizations, 5, pp. 227-248.

Harrison, R., \& Stokes, H. (1992). Diagnosing Organisational Culture. Pfeiffer, San Francisco.

Hartnell, C. A., Ou, A. Y., \& Kinicki, A. (2011). Organizational culture and organizational effectiveness: A meta-analytic investigation of the competing values framework. Journal of Applied Psychology 96, pp. 677-694, figure 2, p. 679. Copyright_c 2011 by the American Psychological Association; reprinted with permission.

Hellriegel, D., Jackson, S. E., Slocum, J., Staude, G., Amos, T., Klopper, H. B., et al. (2004). Management, 2nd edn. South African.

Hofstede, G. (1999). Problems remain, but theories will change: The universal and the specific in 21st - century global management. Organizational Dynamics, 28(1), pp. 34-44.

Jung, T., Scott, T., Davies, H. T. O., Bower, B., Whalley, D., McNally, R., et al. (2009). Instruments for exploring organizational culture: A review of the literature. Public Administration Review, 69, pp. 1087-1096

Kotler, P. (1972). A generic concept of marketing, Journal of Marketing, 36(2), pp. 46-54.

Lunenburg, F. C. (2011). Understanding organizational culture: A key leadership asset. National Forum of Educational Administration and Supervision Journal, 29(4), pp. 1-12.

Madu, B. C. (2008). Organization culture as driver of competitive advantage. Journal of Academic and Business Ethics, 5(1), pp. 1-9.

Magee, K. C. (2002). The impact of organizational culture on the implementation of performance management. Doctoral dissertation, Available from Dissertations and Theses database (UMI No. 3047909).

Maleka, N. K., Kambuwa, M., \& Karodia, A. M. (2015). Assessing organisational culture management and its impact on performance at sew Eurodrive (SA). Arabian Journal of Business and Management Review (Nigerian Chapter), 3(3), pp. 1-27.

Maloney, W. F., \& Federle, M. O (1993). Practical models for organizational assessment. Journal of Management in Engineering, 9(1), pp. 64-81.

Martin, J., \& Simons, R. (2000). Managing Competing Values: Leadership Styles of Mayors and CEOs, Executive Summary, Queensland University of Technology, Australia.

Mayo, E. (1933). The Human Problems of an Industrial Civilization. Macmillan, New York, NY.

Novana, M., \& Ogunlana, S. O. (2006). Organizational culture profile of construction companies in Thailand. In: Conference of Chartered Institute of Bankers (CIB4377), pp. 279-288.

Olanipekun, A. O., Aje, I. O., \& Abiola-Falemu, J. O. (2013). Effects of organizational culture on the performance of quantity surveying firms in Nigeria. International Journal of Humanities and Social Science, 3(5). 
Oney-Yazic, E., Arditi, D., \& Uwakweh, B. O. (2007). Organizational culture in U.S. construction companies. In: Conference of Chartered Institute of Bankers. pp. 219-228.

Peters, T. J., \& Waterman, R. H. (1982). In Search of Excellence: Lessons from America's Best-Run Companies. Harper and Row, New York.

Pettigrew, A. M. (1979). On studying organizational cultures. Administrative Science Quarterly, 24, pp. 570-581.

Roethlisberger, F. J., \& Dickson, W. J. (1939). Management and the Worker. Harvard University Press, Cambridge, MA.
Schein, E. (2010). Organizational Culture and Leadership, 4th edn. Jossey Bass, San Francisco.

Schein, E. H. (2004). Organizational Culture and Leadership. Jossey-Bass, San Francisco.

Siehl, C., \& Martin, J. (1988). Measuring organizational culture: Mixing qualitative and quantitative methods. In: Jones, M. O., Moore, M. D., \& Snyder, R. C. (eds.), Inside Organizations: Understanding the Human Dimension. Sage, Beverly Hills, CA. Suppiah, V., \& Sandhu, M. S. (2012). Organisational culture's influence on tacit knowledge-sharing behaviour. Journal of Knowledge Management, 15(3), pp. 462-477. 